\title{
First line treatment of acute and chronic ATLL with zidovudine (AZT) and interferon alpha (IFN- $\alpha$ ): haematological and molecular responses
}

\author{
Andrew Hodson ${ }^{1 *}$, Maria A Demontis ${ }^{1}$, Nicolas Gillet ${ }^{2}$, Lucy Cook², Charles R M Bangham², Paul Fields ${ }^{3}$, \\ Graham P Taylor'
}

From 15th International Conference on Human Retroviruses: HTLV and Related Viruses

Leuven and Gembloux, Belgium. 5-8 June 2011

\section{Introduction}

Recent data suggest an important role of zidovudine (ZDV) and interferon- $\alpha$ (IFN- $\alpha$ ) in improving response rates and survival in acute ATLL. Treatment of chronic ATLL with ZDV/IFN- $\alpha$ alone has recently been associated with $100 \%$ survival beyond five years.

\section{Methods}

Retrospective analysis of patients with acute and chronic ATLL treated with ZDV/IFN- $\alpha$ first line. Response was assessed one month from the start of treatment using total lymphocyte and CD4 count, HTLV-1 proviral load (PVL) and clonal analysis (in house method).

\section{Results}

Acute ATLL: response rate 33\% (1 CR, 2 PR). Median overall survival (OS) 3 months (range 3-8).

Chronic ATLL: response rate 100\% (4 CR, 1 PR). Median OS 20 months (range 9-73). In chronic ATLL these prolonged responses were observed despite lower dose therapy. Two patients, showed 10-fold reductions in PVL which occurred more than 1 year after haematological CR. All patients remain in remission at time of analysis. Clonality studies demonstrated a dominant clone at base line with emergence of a polyclonal pattern after viral load reduction.

\section{Discussion}

The complete response in one patient with acute ATLL supports the recent observation that $\mathrm{ZDV} / \mathrm{IFN}-\alpha$ is effective as first line treatment in some patients.

\footnotetext{
* Correspondence: a.hodson10@imperial.ac.uk

${ }^{1}$ Section of Infectious Diseases, Wright-Fleming Institute, Imperial College London, London, UK

Full list of author information is available at the end of the article
}

The significant reduction in PVL and late emergence of a polyclonal integration pattern suggest benefit from prolonged ZDV/IFN-a therapy in chronic ATLL and the utility of both PVL and clonal analysis as a test of the efficacy of novel treatment regimes.

\section{Author details}

${ }^{1}$ Section of Infectious Diseases, Wright-Fleming Institute, Imperial College London, London, UK. ${ }^{2}$ Department of Immunology, Wright-Fleming Institute, Imperial College London, London, UK. ${ }^{3}$ Department of Haematology, Guy's and St Thomas' NHS Foundation Trust, London, UK.

Published: 6 June 2011

doi:10.1186/1742-4690-8-S1-A53

Cite this article as: Hodson et al.: First line treatment of acute and chronic ATLL with zidovudine (AZT) and interferon alpha (IFN- $\alpha$ ): haematological and molecular responses. Retrovirology 2011 8(Suppl 1):A53.

Submit your next manuscript to BioMed Central and take full advantage of:

- Convenient online submission

- Thorough peer review

- No space constraints or color figure charges

- Immediate publication on acceptance

- Inclusion in PubMed, CAS, Scopus and Google Scholar

- Research which is freely available for redistribution

Submit your manuscript at www.biomedcentral.com/submit Ciomed Central

\section{Biomed Central}

(c) 2011 Hodson et al; licensee BioMed Central Ltd. This is an open access article distributed under the terms of the Creative Commons Attribution License (http://creativecommons.org/licenses/by/2.0), which permits unrestricted use, distribution, and reproduction in any medium, provided the original work is properly cited. 